\title{
EVALUATION OF THE POLLUTION STATUS OF RIVER GALMA BASIN IN THE VICINITY OF DAKACE INDUSTRIAL LAYOUT, ZARIA, NIGERIA
}

\author{
Udiba Udiba Ugumanim', Bate Garba Barde", Mahmood Abdullahi', Umar Shitu', Zakariyya Ahmad', Agboun \\ Temeweidoubra Debora', Ozogu Agbe Nanadeinboemil \\ I - National Research Institute for Chemical Technology, Zaria, Nigeria \\ II- Federal University Dutse, Dutse, Nigeria
}

\section{ABSTRACT}

Dakace Industrial Layout Zaria habours a number of wet industries, effluents from these industries are discharged through drains and canal that empties into River Galma. The river basin is a booming agricultural area and the river is used for irrigation. A study was conducted at River Galma Basin around Dakace Industrial Layout Zaria to evaluate its heavy metal pollution status. Lead $(\mathrm{Pb})$, chromium $(\mathrm{Cr})$, nickel $(\mathrm{Ni})$ and manganese $(\mathrm{Mn})$ concentrations were analyzed using Shimadzu atomic absorption spectrophotometer (model AA-6800, Japan) after wet digestion. The range of concentrations $(\mathrm{mg} / \mathrm{kg})$ of these metals was $\mathrm{Pb}$ (52.77-120.40), $\mathrm{Cr}(0.56-8.05), \mathrm{Ni}(0.17-4.01)$ and $\mathrm{Mn}(6.98-22$.). The heavy metals concentrations determined were found to be within US EPA, World Health Organization (WHO) and Food and Agricultural Organization (FAO) limits for acceptable soil metal concentrations. However, the mean soil lead level was found to be above Dutch Target value $(85 \mathrm{mg} / \mathrm{kg})$ which is the bench mark for soil quality. Statistical analysis shows that industrial discharges from Dakace industrial layout have significant influence on the heavy metal profile of the study area. The implications of these findings for public health are fully discussed.

\section{UDC \& KEYWORDS}

- UDC: 504 - RIVER GALMA - EFFLUENTS | HEAVY METAL - POLLUTION $\because$ FAO LIMITS

\section{INTRODUCTION}

Waste is the unwanted, useless or discarded materials generated from residential, industrial and commercial activities. It may be categorized according to its origin (domestic, industrial, commercial, construction or institutional); according to its contents (organic material, glass, metal, plastic, paper etc); or according to hazard potential (toxic, non-toxin, flammable, radioactive, infectious etc) (UNEP, 2000). Waste could also be referred to as "end of use" material, and is used to describe a substance that has come to the end of its usefulness in a given process. Such substances that are no longer useful in a specified process could broadly be classified into three categories: the first category is made up of substances which though no longer useful in the particular process, contain nutrients or energies that is needed by the environment. Waste in this category is called a resource. The second category of waste is called nuisance and consists of wastes that are inert or neutral to the environment. They are no longer useful in the process, they are not needed by the environment and their presence does not pose any toxicological risk in the environment. The third category is called pollutants and comprises of wastes that have the potential to cause pollution. The difference between a resource, nuisance and pollutant is a function of the characteristics of the receiving environment, the quality/ quantity of waste and the timing of discharge. A wide range of organic and inorganic waste is

'udiba.udiba@yahoo.com

www.journals.cz generated from anthropogenic activities. Most often, micro organism present in the environment naturally acts on the organic components of the waste breaking them down to relatively harmless substances. The inorganic components containing heavy metals on the other hand, are not easily decomposed and thus require immobilization or physical removal (Ogbona et al., 2009). Pollution occurs when waste is generated in such a magnitude or quality that it destroys the natural balance of organism, interfere with productivity and extinct or dislocate the normal users of the environment. GESAMP, (1991) defined pollution as the production and/or introduction by man, directly or indirectly of substance or energies into the environment resulting in deleterious effects of such nature as to endanger human health, harm other living resources in the ecosystem and impair or interfere with amenities or other legitimate use of the environment. Pollution of the general environment has increasingly gathered a global interest as large quantities of pollutants have continuously been introduced into ecosystems as a consequence of urbanization and industrial processes. The problems and major environmental concerns associated with the dispersal or disposal of anthropogenic (industrial, agricultural and urban municipal) wastes is the contamination of the soil, water and air. The ever-growing global concern over the release and subsequent deposition of heavy metals in soils cannot therefore be overemphasized (Bvenura and Afolayan, 2012). Heavy metals occur naturally at low concentrations in soils. However, they are considered as soil contaminants due to their widespread occurrence, acute and chronic toxicity (Chopra, 2009). Heavy metal contamination of soils through anthropogenic activities is a widespread and serious problem confronting scientists and regulators throughout the world. Contamination of the soil environment by heavy metals occurs mostly in areas with high influence of anthropogenic activities; hence the release of heavy metals has often been linked with soils in urban areas, usually near industrial sites and agricultural lands (Bvenura and Afolayan, 2012). Some of such anthropogenic activities that have significant adverse impact on the geochemical environment include mining and smelting of metallic ores together with a number of agricultural, industrial and domestic activities. Soils provide a suitable natural environment for biodegradation of wastes and therefore serve as a sink for the adsorption and absorption of ions and as a medium for the restoration of vegetation and normal land use (Ekundayo, 2003). High concentrations of metals do not only pollute soils but also surface and ground water, and subsequently find their way into the plants. Soils contain both macro and microorganisms which are all necessary to support the growth of plant. A number of studies have identified serious toxicological risks in relation to increased soil metal concentration and consequent plant uptake (Larbie et al., 2014; Yebpella et al., 2011; Udiba et al., 2013). Many of such studies have shown that heavy metals are extremely persistent in the environment, non biodegradable, non thermo- degradable and readily accumulate to toxic levels. They can accumulate to phytotoxic levels, especially in low $\mathrm{pH}$ soils, which 
reduces plant growth and enter the food chain when plants are consumed by animals (Matini et al., 2011). Even at low concentrations in the animals, most of them are said to be toxic because there is no good mechanism for their elimination from the body. Contamination of agricultural soils with heavy metals has always been considered a critical challenge in scientific community and various industries are playing a key role in this context by discharging a large amount of effluents on the soils and into surface water. Major contributions of heavy metal contamination in soils come from the use of discharged industrial effluent and domestic sewage directly on earth surface for irrigation purposes (Chopra et al., 2009).Like many other streams and rivers that flow through cities in developing countries, River Galma is used as receptacle for domestic, agricultural and most importantly industrial waste. Previous studies have seriously implicated the surface water of River Galma around Dakace industrial layout for heavy metal pollution (Udiba et al., 2014a, Udiba et al., 2014b). The possibility of heavy metal contamination of River Galma basin and crops grown on it around Dakace industrial layout cannot be completely ruled out especially in the dry season when the contaminated water is used for irrigation. Metals are persistent pollutants that can be biomagnified in the food chains, becoming increasingly dangerous to human and wildlife. Assessing pollutants in different components of the ecosystem has therefore become an important task in preventing risk to natural life and public health. In this study, lead, chromium, manganese and nickel status of River Galma Basin around Dakace industrial layout was thoroughly evaluated and implications for public health fully discussed.

\section{Materials and Methods}

\section{Sampling Area}

Zaria, a city in Kaduna State, Northern Nigeria is located at latitude $11^{\circ} 3^{\prime} \mathrm{N}$ and longitude $7^{\circ} 40^{\prime} \mathrm{E}$. The city is about 128 $\mathrm{km}$ South- East of Kano and $64 \mathrm{~km}$ North-East of Kaduna, the State capital (Nnaji et al., 2011). River Galma is the main drainage channel in Zaria since other rivers and streams discharge into it. The river is located at the southeastern part of Zaria and its source is the Jos Plateau. The Zaria dam is located on River Galma (Nnaii et al., 2007). Dakace industrial area habours a number of wet industries such as oil mills, packaging, food and beverages industries. Effluents from these industries are discharged through drains and canal that empties into the River. The Galma river basin is a booming agricultural area. Crops are planted on both sides of the riverbank throughout the year. Fertilizers, herbicides and insecticides are used on these crops and are eventually washed into the river via surface runoff (Nnaji et al., 2011). The river is a major source of water supply to a number of communities located along its course. It is used for irrigation, fishing, bathing and even drinking. The river carries water throughout the year with its peak discharge in the month of July or August and least discharge in March or April (Thorp, 1970). The geology of the study area is basement of complex rock composed mainly of fine grain gneisses and migmatite with some coarse-grained granite outcrop in few places. The gneisses are moderately to weakly floated, primarily made up of quartz and oligoclase, depth of weathering is regular but thorough, the depth ranges from 10 meters to deep pocket, occasionally extending to about 60 meter. Due to poor conservation and land use practice like extensive vegetation clearance for agricultural and urban development purposes, intensive grazing, livestock tracks and human foot paths criss-crossing the area overland flow, rilling and gullying have become the dominant mode of rain water disposal from the landscape. (Ologe,
1971; Bello, 1973; and Iguisi, 1996).The catchment area lies in the natural vegetation zone known as the Northern Guinea Savannah. Unfortunately, this characteristic vegetation cover is hardly preserved due to urbanization and other Anthropogenic activities and poor management practices, like cultivation, intensive grazing, fuel wood harvesting and annual bush burning (Ologe, 1971). Rainfed agriculture and irrigation are the two major forms of agricultural activities practice in the Galma catchment. The rainfed agriculture is a rainy season activity which takes place on the upland fields.

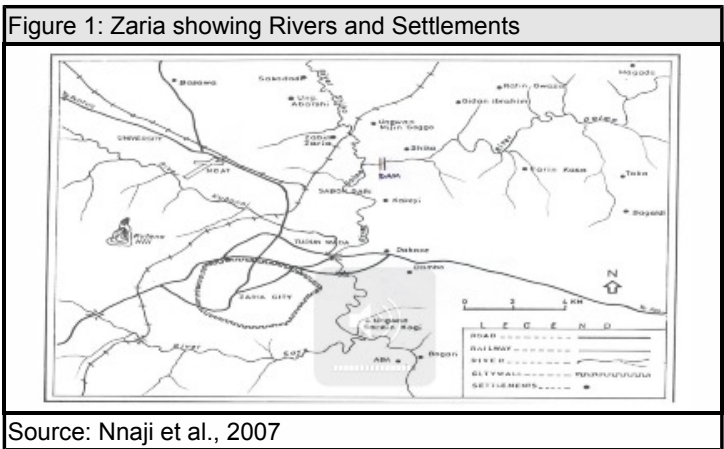

Collection, Preservation and preparation of soil samples

Procedure for sample collection, preservation and preparation was adopted from Abida (2009). Four sampling points were established along Galma River basin around Dakace industrial layout after identifying effluent discharge points (point sources) from the industries. Sampling point A was 500 meters upstream of the industrial layout. Sampling point B was at the first identified point source in industria layout. Sampling point $C$ was after the second and third identified effluent discharge points about 200 meters from sampling point B. Sampling point D was 200 meters from sampling point $C$.Soil samples were collected at the surface level $(0-10 \mathrm{~cm}$ depth) from the four established sampling point using hand trowel. The soil samples collected were stored in black polythene bags and transported to the environmental laboratory of National Research Institute for Chemical Technology (NARICT), Zaria, Nigeria. Soil samples from each point was thoroughly mixed to obtain a representative sample, air dried, crushed and sieved with $2 \mathrm{~mm}$ mesh before wet digestion. Well-mixed samples of $1 \mathrm{~g}$ each was taken in $250 \mathrm{ml}$ glass beakers and digested with $10 \mathrm{ml}$ of concentrated nitric acid, perchloric acid and hydrofluoric acid in the ratio $3: 1: 1$ on a hot plate. After evaporation to near dryness, the samples were dissolved with $10 \mathrm{ml}$ of $2 \%$ nitric acid, filtered and then made up to 50 $\mathrm{ml}$ with distilled, deionized water.

\section{Sample Analysis}

Metal concentration in the digests was determined by Atomic Absorption Spectrophotometry, using shemadzu Atomic Absorption Spectrophotometer (model AA-6800, Japan) equipped with Zeaman background correction and graphite furnace at National Research Institute for Chemical Technology (NARICT), Zaria-Nigeria. The calibration curve was prepared by running different concentrations of standard solutions. The instrument was set to zero by running the respective reagent blanks. Average values of three replicates were taken for each determination and were subjected to statistical analysis

\section{Analytical Quality Assurance}

In order to check the reliability of the analytical methods employed for metal determination, one blank and combine standards were run with every batch to detect background 
contamination and monitor consistency between batches. The result of the analysis was validated by digesting and analyzing Standard Reference Materials, Lichen coded IAEA-336 following the same procedure. The analyzed values and the certified reference values of the elements determined were compared to ascertain the reliability of the analytical method employed. The reagent used for sample preservation and digestion, viz. nitric acid, perchloric acid and hydrofluoric acid (Riedel-deHaën, Germany), were of analytical grade.

\section{Statistical Analysis}

All statistical analyses were done by SPSS software 17.0 for windows.

\section{Results}

To evaluate the accuracy and precision of the analytical procedure employed, standard reference material of Lichen coded IAEA -336 was analyzed in like manner to our samples. The analyzed values and the certified reference values of the elements determined were very close (Table 1), suggesting the reliability of the method employed.

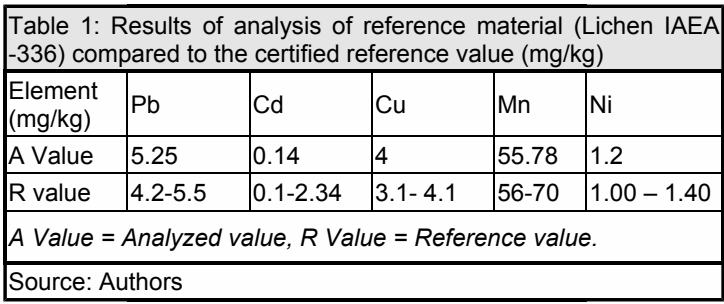

The Mean concentration and standard deviation of lead, chromium, manganese and nickel of soil samples from the four established sampling points along River Galma basin, around Dakace Industrial Estate, are presented in Table 2. Spatial distributions of soil lead, chromium, manganese and nickel concentration across sampling stations along River Galma basin are presented in figures 2,3,4, and 5.

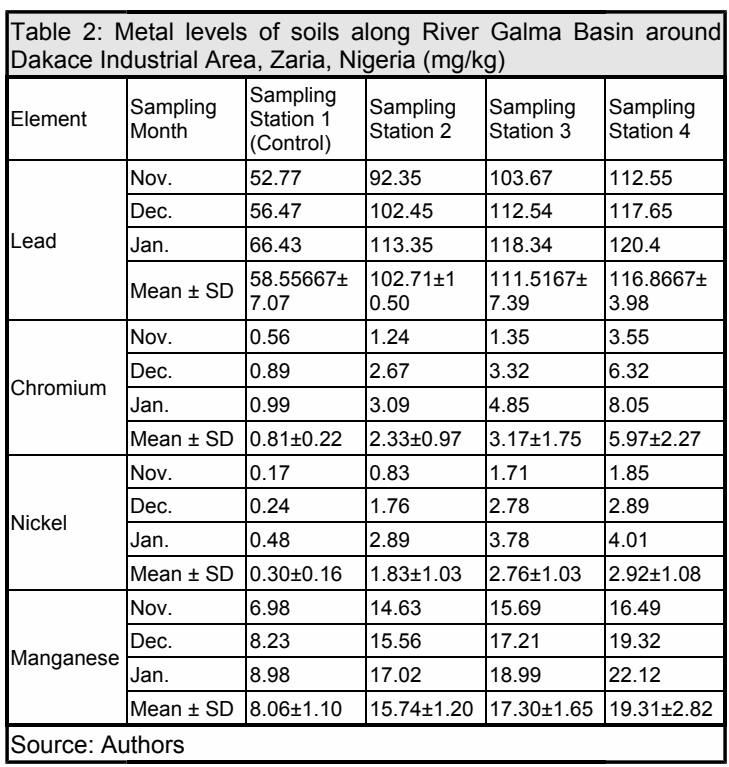

Results obtained from the determination of soil metal content across the different sampling points along River Galma Basin, Zaria, Nigeria (Table 2) indicates that the order of detection of lead in soil was; Sampling Station $4>$ Sampling Station 3>Sampling Station 2>Sampling Station 1. The concentration ranged between $52.77 \mathrm{mg} / \mathrm{kg}-120.40 \mathrm{mg} / \mathrm{kg}$ The lowest concentration $(52.77 \mathrm{mg} / \mathrm{kg})$ was recorded in Sampling Station 1 in the month of November and the highest concentration $(120.40 \mathrm{mg} / \mathrm{kg})$ in Sampling Station 4 in January. The mean soil lead levels of River Galma basin increased with increasing distance downstream throughout the sampling period. Statistical analysis shows that the difference in soil lead levels across the sampling stations was statistically significant (ANOVA, $p<0.05$ ), sampling station 1 being significantly lower than sampling stations 2 , 3 , and 4 . The difference in soil lead levels between sampling station 2 and 3 , sampling station 3 and 4 , and between sampling station 2 and 4 were not statistically significant (ANOVA $p>0.05$ ). The overall mean soil lead levels along River Galma basin (Study area) was found to be $97.41 \pm 24.88 \mathrm{mg} / \mathrm{kg}$.

Table 2 shows that chromium concentration followed the order: Sampling Station >Sampling Station 3>Sampling Station 2>Sampling Station 1. The concentration ranged between $0.56 \mathrm{mg} / \mathrm{kg}-8.05 \mathrm{mg} / \mathrm{kg}$. The lowest concentration $(0.56 \mathrm{mg} / \mathrm{kg})$ was recorded in Sampling Station 1 in the month of November and the highest concentration $(8.05 \mathrm{mg} / \mathrm{kg})$ in Sampling Station 4 in January. The mean soil chromium levels of River Galma basin also increased with increasing distance downstream throughout the sampling period. Statistical analysis shows that the difference in soil chromium levels across the sampling stations was found to be statistically significant (ANOVA, $p>0.05$ ). Soil chromium concentration at sampling station 4 was significantly higher than that at sampling station 1 and 2. The overall mean soil chromium levels along River Galma basin (Study area) was $3.07 \pm 2.35 \mathrm{mg} / \mathrm{kg}$.

Nickel concentration obtained from the determination of soil metal content across the established sampling points along River Galma basin, Zaria (Table 2) showed the trend sampling station $4>$ sampling station $3>$ sampling station $2>$ sampling station 1 . The concentration ranged between $0.17 \mathrm{mg} / \mathrm{kg}-4.01 \mathrm{mg} / \mathrm{kg}$. The lowest concentration $(0.17 \mathrm{mg} / \mathrm{kg})$ was recorded in sampling station 1 , in the month of November and the highest concentration $(4.01 \mathrm{mg} / \mathrm{kg})$ in sampling station 4 in January. The mean soil nickel levels of River Galma basin also increased with increasing distance downstream throughout the sampling period.

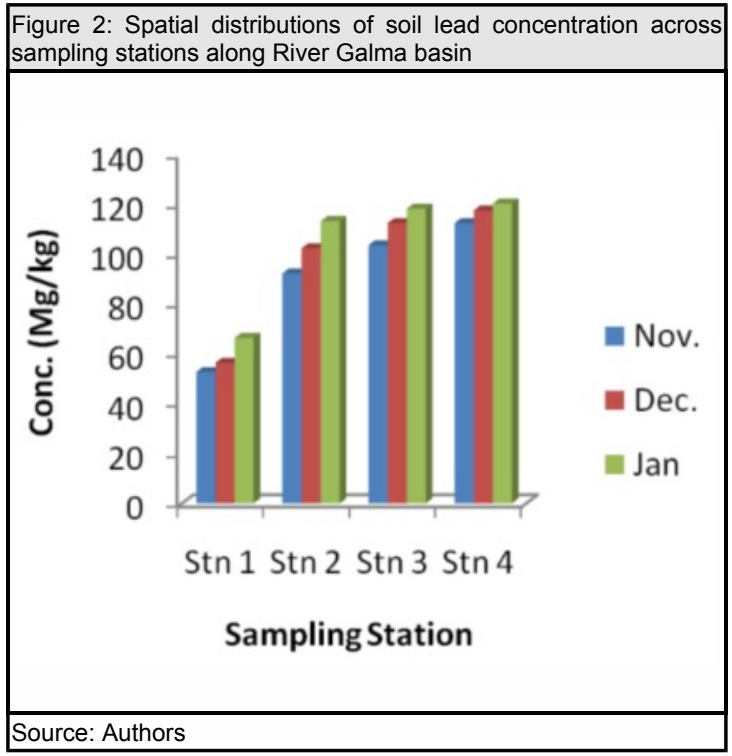



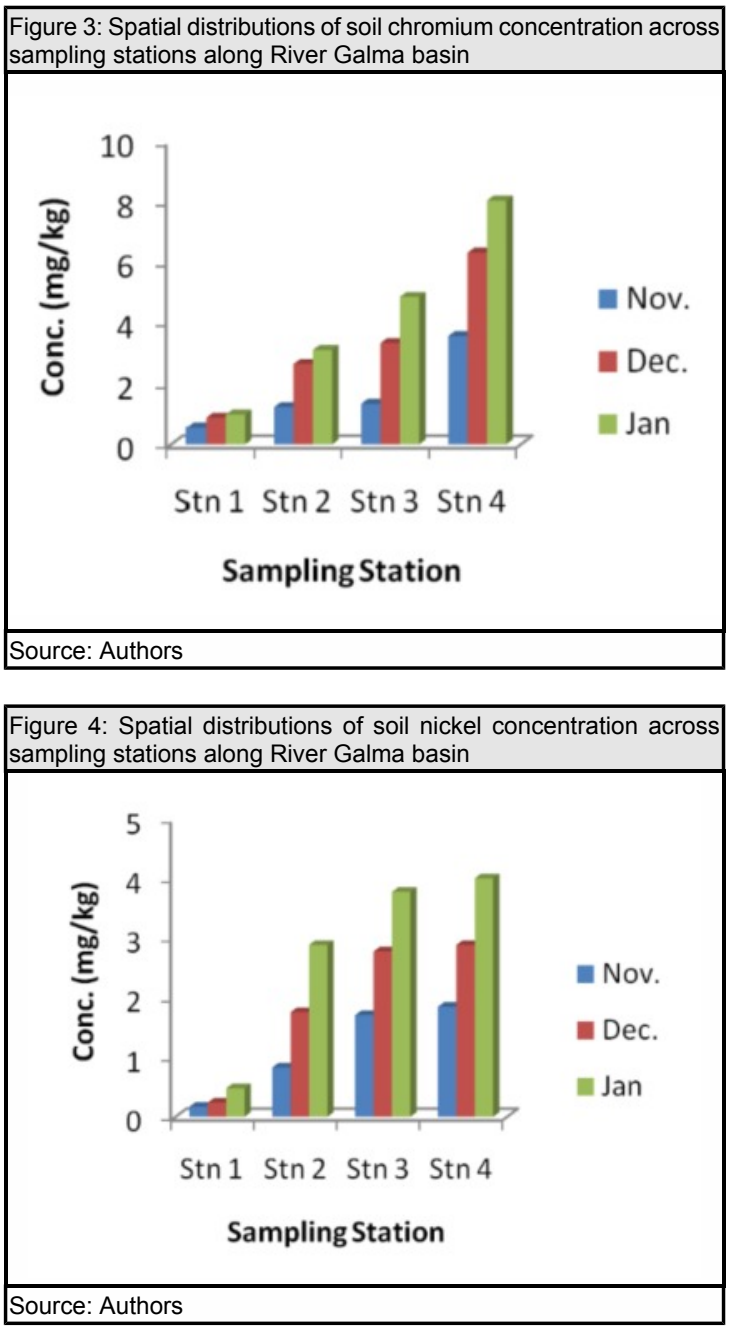

Figure 5: Spatial distributions of soil manganese concentration across sampling stations along River Galma basin

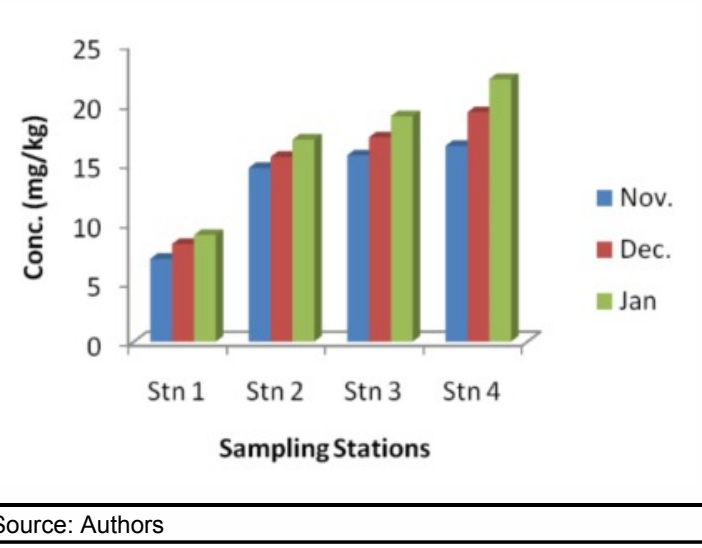

Statistical analysis shows that the difference in soil nickel levels across the sampling stations was statistically significant (ANOVA, $P<0.05$ ), sampling stations 3 and 4 being significantly higher than sampling station 1 . The overall mean soil nickel concentration along River Galma basin (Study area) was found to be $1.95 \pm 1.33 \mathrm{mg} / \mathrm{kg}$.
Soil manganese concentration in the study followed the sequence: Sampling Station 4 >Sampling Station $3>$ Sampling Station 2>Sampling Station 1 . The concentration ranged between $6.98 \mathrm{mg} / \mathrm{kg}-22.12 \mathrm{mg} / \mathrm{kg}$. The lowest concentration $(6.98 \mathrm{mg} / \mathrm{kg})$ was recorded in Sampling Station 1 in the month of November and the highest concentration $(22.12 \mathrm{mg} / \mathrm{kg}$ ) in Sampling Station 4 in January. The mean soil manganese levels of River Galma basin also increased with increasing distance downstream throughout the sampling period. Statistical analysis shows that the difference in soil manganese levels across the sampling stations was statistically significant (ANOVA, $p<$ 0.05). Soil manganese concentration at sampling station 1 was significantly lower than the concentrations at sampling stations 2,3 , and 4 respectively. The overall mean soil manganese level along River Galma basin (Study area) was found to be $15.10 \pm 4.70 \mathrm{mg} / \mathrm{kg}$.

Figure 6: Spatial distributions of overall average soil metal concentration across sampling stations along River Galma basin

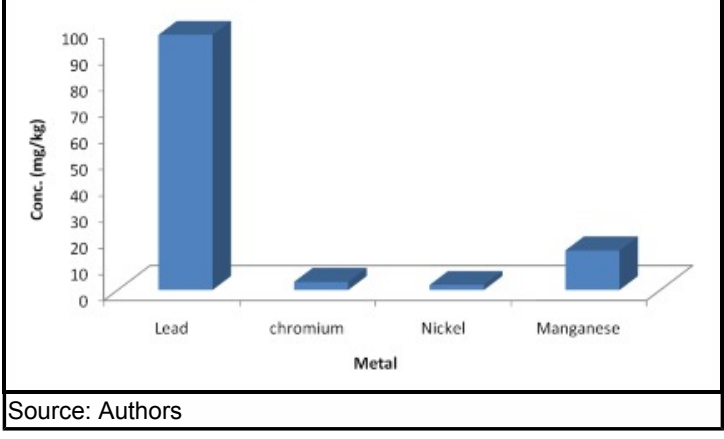

The spatial distribution of the Average soil metal concentration in the study (Figure 6 ) shows that the trend of occurrence of the heavy metals in the study area was Lead $>$ manganese $>$ chromium $>$ nickel. Strong positive correlation was observed between lead and chromium $(r=0.764)$ and between nickel $(r=0.899)$, and manganese $(r=0.973)$. Positive correlation was also observed between chromium and manganese $(r=0.860)$, chromium and nickel $(r=0.884)$, and between nickel and manganese $(r=0.931)$. The correlations were statistically significant at $95 \%$ confidence level.

\section{Discussion}

The increase in soil lead level downstream may be due to increase in surface runoff of agricultural, industrial and domestic discharges from points and non point sources along the profile of the river basin downstream. It could be noted that the first sampling point was established upstream of Dakace industrial layout about 500 meters from the first identified effluent discharge point. This sampling point is characterized mainly by influx of waste from agricultural activities through surface runoff and open dumping. Sampling station 1 thus served as control in assessing the influence of Dakace industrial area on the heavy metal profile of the River Galma basin. The second sampling point about 200 meters away from sampling point 1 was located at the first effluent discharge point and receives anthropogenic inputs from agricultural, domestic and industrial discharges. The third sampling point which was 200 meters from the second also received anthropogenic discharges from agricultural, domestic and industrial activities. The inhabitants of the villages along the river are mainly peasant farmers, hence the land is subjected to intensive seasonal farming. Rainfed agriculture and irrigation are the two major forms of agricultural activities 
practice in the Galma catchment. The rainfed agriculture is a rainy season activity. Irrigation farming where farmers divert flowing water into their farmland, or use machines or pumping device to supply water to their farmland is practiced in the dry season. Udiba et al., 2014b reported that lead content of the surface water of River Galma increases with increasing distance downstream within Dakace industrial layout. The use of surface water with increasing lead level downstream for irrigation may also be responsible for the increase in soil lead levels downstream. Again rising population, continuous cultivation and intense grazing is posing a serious environmental threat, in terms of upstream soils loss and downstream deposition which may also account for this observation

The overall mean soil lead level $110.37 \pm 18 \mathrm{mg} / \mathrm{kg}$ was found to be lower than USEPA guidelines for lead soil level (400 $\mathrm{mg} / \mathrm{kg}$ ). The observed mean soil lead level was also found to be lower than Dutch intervention value $(530 \mathrm{mg} / \mathrm{kg})$, a level above which the functional properties of the soil for plant, animals and human's life are considered to be seriously impaired. The findings of this study Indicates that River Galma basin is fit for agricultural purposes and does not pose any threat with respect to lead contamination. However, the mean soil lead level around River Galma basin was found to be above Dutch Target value $(85 \mathrm{mg} / \mathrm{kg}$ ) which is the bench mark for soil quality. A soil leads level below which all the functional soil properties for plant, animals, and human's are considered to have been fully recovered. The significant differences observed in soil lead levels between sampling station 1 (500 meters before the industrial layoutcontrol) and sampling stations 2,3 and 4 within the industrial area indicates that the industrial area has significant adverse effect on the lead profile of the area under study. The increase in lead levels as the dry season progresses could be attribute to the fact that the volume of water in the river decreases, the speed also decrease and the water becomes more concentrated with the effluents discharged into it as the dry season becomes more severe. The use of more contaminated water for irrigation thus account for the increase in soil lead levels. In her study in Nairobi, Cathrines (2009) showed that, lead accumulation in the soil could be attributed to long term continuous application of waste water from industrial and agricultural waste. Soil lead levels ranging from $10.10 \mathrm{mg} / \mathrm{kg}$ to $73.83 \mathrm{mg} / \mathrm{kg}$ was reported for top soil $(0.10 \mathrm{~cm}$ ) in Umuahia, Nigeria (Ogbonna and Okeke, 2011). A higher range of $35.9 \mathrm{mg} / \mathrm{kg}$ to $306.7 \mathrm{mg} / \mathrm{kg}$ for dry season, and $24.00 \mathrm{mg} / \mathrm{kg}$ to $316.14 \mathrm{mg} / \mathrm{kg}$ for wet season were reported in Yauri, Nigria (Yahaya et al., 2010). Lead levels ranging from $89 \mathrm{mg} / \mathrm{kg}$ to $134 \mathrm{mg} / \mathrm{kg}$ was reported for Segura River Valley in Spain (Mico et al., 2006). A significantly higher range of 81.65 to $684.27 \mathrm{mg} / \mathrm{kg}$ dry weight was reported in Dareta village immediately after the remediation exercise (Udiba et al., 2012a). Exposure to low lead levels over prolonged period leads to chronic poisoning (it accumulates in the body and can build to toxic level under continuous exposure). Lead is one of the limited classes of element that can be described as purely toxic. Most other elements though toxic at high concentration are actually required nutrients at lower levels (Udiba et al., 2012 a). There is no exposure level below which lead appear to be safe. Lead is number 2 in the Agency for Toxic Substances and Disease Registry (ATSDR) Top 20 list, and account for most of the cases of pediatric heavy metal poisoning. It interferes with the normal development of a child's brain and nervous system, therefore children are at greater risk of lead toxicity. The effect on peripheral nervous system on the other hand, is more pronounced in adults. Lead absorption constitutes serious risk to public health. It induces reduced cognitive development and intellectual performance in children, increased blood pressure, and cardiovascular diseases in adult as well as liver and kidney dysfunction (Udiba et al., 2012a).

The increase in soil chromium level downstream may be due to increased activities on the river basin. It could be recalled that the river around the study area receives urban runoff, industrial effluent, seepages, waste from agricultural farmlands and other anthropogenic activities. These have compromised the water quality and the surrounding soil by way of pollution with poisonous chemical and heavy metal. These activities may be responsible for the increase in chromium levels downstream. The overall mean soil chromium level $(3.07 \pm 2.35 \mathrm{mg} / \mathrm{kg})$ was found to be lower than (WHO, FAO) guideline for soil chromium level of 300 and $100 \mathrm{mg} / \mathrm{kg}$ respectively (Adu et al., 2012), hence, chromium was not implicated in the study. River Galma basin could be said to be fit for agricultural purposes with particular reference to pollution by chromium as it poses no toxicological risk. The significant difference observed in soil chromium level between sampling station 1 (control) and the station 4 suggest anthropogenic inputs from industrial, domestic and agricultural activities. A mean concentration of $0.003 \pm 0.0041 \mathrm{mg} / \mathrm{kg}$ at $15 \mathrm{~cm}$ and $0.001 \pm 0.000 \mathrm{mg} / \mathrm{kg}$ at $10 \mathrm{~cm}$ along the Badagry expressway was reported (Adu et al., 2012). $4.3 \mathrm{mg} / \mathrm{kg}$ was reported for Udege area of Nasarawa State, Nigeria (Aremuet al., 2010a). $9.68 \mathrm{mg} / \mathrm{kg}$ was reported for Azare derelict Barite area of Nasarawa State, Nigeria. (Aremuet al., 2010b). When chromium concentration range obtained from this study was compared to the level from similar studies in other countries, the value was lower than finding in US $(2.44-69.4 \mu \mathrm{g} / \mathrm{g})$, Poland $(3.7-75.8 \mu \mathrm{g} / \mathrm{g})$ and Ethiopia $(86.3-1570 \mu \mathrm{g} / \mathrm{g})$ (Yahaya et al., 2010). The mean concentration of chromium occurring naturally in the earth's normal mineral soil is about 200 $\mathrm{mg} / \mathrm{kg}$ worldwide (Udiba et al., 2012; Hawkes and Webb, 1962). Chromium ( $\mathrm{Cr}$ ) is considered as essential nutrient and a health hazard. Hexavalent chromium $[\mathrm{Cr}(\mathrm{VI})]$ is considered harmful even in small intake quantity (does) whereas trivalent chromium [ $\mathrm{Cr}(\mathrm{III})]$ is considered essential for good health at moderate intake (Ezike et al.,2012). Chromium is a toxic human carcinogen that causes or increases the rate of cancer; ingestion of high concentration often results in lung function and blood system problems, gastrointestinal burns, hemorrhage, generalized oedema, pulmonary oedema, liver damage and kidney damage. Symptoms are diarrhea, abdominal pain, indigestion and vomiting. Death may be the result of pulmonary or cardiac arrest. Skin contact causes a number of skin problems including rashes and sores (Udiba et al., 2012).

The three sampling stations (stations 2, 3 and 4) along River Galma basin around Dakace industrial area are greatly influenced by the River which is used for the irrigation of the farms. The increase in soil nickel level observed downstream (Table 2) may be as a result of the increase in the volume of waste carried downstream by surface runoffs as well $s$ the increase in waste load of the water used for irrigation. The increase in nickel concentration as the dry season progress with the highest value at the peak of the dry season could be attributed to decrease in the volume of water and the corresponding increase in the concentration of the waste. The overall mean soil nickel level $(2.50 \pm 16$ $\mathrm{mg} / \mathrm{kg}$ ) was found to be lower than the $50 \mathrm{mg} / \mathrm{kg}$ set by WHO and FAO as the guideline for nickel concentration in agricultural soils. The United States Environmental Protection Agency (USEPA) Maximum Permissible Limit (MPL) for nickel in soil as well as the European Union Regulatory Standards for nickel in soil is $50 \mathrm{mg} / \mathrm{kg}$ (Udiba 
et al., 2012b). Nickel therefore poses no toxicological risk to cultivated crops along River Galma basin. The significant differences observed in soil nickel level within the study area (Dakace industrial area) and the control (500 meters upstream of Dakace industrial area) may be due to influence of higher levels of industrial and other anthropogenic activities around the industrial layout on the River Galma basin. A Similar mean soil nickel concentration of $2.31 \mathrm{ppm}$ was reported by Aremuet al., (2010a) for Azara derelic area of Nasarawa State, Nigeria. A higher mean value of $6.6 \pm 08$ was reported for soil never exposed to waste water irrigation and $55.0 \pm .04 \mathrm{ppm}$ for soil exposed to long term waste water irrigation in Zimbabwe (Monsana, 2011). A range of 2.44$6.04 \mu \mathrm{g} / \mathrm{g}$ was recorded in US soils, $7.709 \mu \mathrm{g} / \mathrm{g}$ for China, 47.3-2006 $\mu \mathrm{g} / \mathrm{g}$ for Ethiopia (Yahaya et al., 2010). Nickel occurs naturally in soil as a result of the weathering of the parent rock. The underlying rocks and soil-forming processes strongly influence the amount of nickel in soil. Anthropogenic activities have resulted in the widespread atmospheric deposition of the metal. Small amount of nickel is needed by the human body to produce red blood cells, however, when the concentration exceeds a certain threshold, can cause decreased body weight, heart and liver damage, thyroid disease, cancer and skin irritation (Udiba et al., 2012b). Other toxic effects of nickel observed following chronic exposure including bronchitis, emplysema, reduced vital capacity and asthma.

The increase in soil manganese level downstream along River Galma basin may be as a result of the increase waste from industrial, municipal, agricultural and other anthropogenic activities along the profile of the River. The overall mean soil manganese level $(17.48 \pm 0.7 \mathrm{mg} / \mathrm{kg})$ was found to be lower than WHO and FAO ( $80 \mathrm{ppm})$ guidelines for soil manganese level in irrigated soil. The heavy metal level in the study was within the background level range for farming. The mean level $(8.06 \pm 03 \mathrm{mg} / \mathrm{kg})$ of manganese obtained from the control station was lower than those obtained from the soil of the irrigated farmland around Dakace industrial layout. This reflects a contamination of soils of this irrigated farmland by the heavy metal from anthropogenic activities around the layout. The level of manganese in this study were lower when compared with (119.62 ppm) of Azare derelict area of Nasarawa State, Nigeria (Aremu et al., 2011). 13.81 \pm 0.01 , and 15.12 \pm 0.26 were recorded in Alau and Gongulon in Maiduguri, Nigeria (Aremu et al, 2010b \& Uwah et al., 2009).Manganese toxicity may result in multiple neurological problems (Keen et al, 2001). The effects of early exposure may not appear until many years later. In its worst form, manganese toxicity can result in a permanent neurological disorder with symptoms similar to those of Parkinson's disease, including tremors, difficulty in walking and facial muscle spasms (udiba et al., 2012b).

The overall metal (Figure 6) concentration in the study followed the trend lead $>$ manganese $>$ chromium $>$ nickel. The strong positive correlation observed between lead and chromium ( $r=0.838)$, lead and nickel $(r=0.916)$, and between lead and manganese $(r=0.859)$ indicates that as soil lead level increases, the level of chromium, nickel, and Manganese also increases suggesting that the same source may be responsible for the presence of these metals at concentration determine. The strong positive correlation observed between chromium and manganese $(r=0.970)$, chromium and nickel $(r=0.832)$, and between nickel and manganese $(r=0.908)$ also indicates that as the level of chromium in soil increases, the level of manganese and nickel also increases, and as the level of nickel increases the level of manganese also increases suggesting same source may be responsible for the presence of the metals at the stated concentration. All the correlations were statistically significant at $95 \%$ confidence level.

\section{CONCLUSION}

The findings of this study Indicates that River Galma basin around Dakace industrial layout is fit for agricultural purposes and does not pose any threat with respect to lead, chromium, nickel and manganese intoxication. However, the mean soil lead level was found to be above Dutch Target value $(85 \mathrm{mg} / \mathrm{kg})$ which is the bench mark for soil quality. A soil leads level below which all the functional soil properties plant, animals, and human's are considered to have been fully recovered. The significant differences observed in soil metal levels between the control and the study area indicates that Dakace industrial area has a significant influence on the heavy metal profile of the basin No matter how low the levels of heavy metals in the environment are, their presence is not desirable as accumulation to toxic level over time cannot be completely ruled out. Imposition of direct charges on industrial effluents by the regulating agency, as well as continuous monitoring and surveillance is imperative in order to ensure the protection of land and water resources from further degradation.

\section{Acknowledgement}

The research team wishes to express her profound gratitude to the National Research Institute for Chemical Technology (NARICT), Zaria-Nigeria, for making their environment laboratory available for this research work.

\section{REFERENCES}

Abida, B., Ramaiah, M., Harikrishna, Khan I. and Veena, K. (2009) Analysis of Heavy Metals concentration in Soil and Lichens from various Localities of Hosur Road, Bangalore, India Journal of Chemistry 6 (1) 13 - 22.

Adu, O. O. (2012). Survey of Post Harvest Losses in Maize. $19^{\text {th }}$ Annual Rep. Nigeria Stored Product Research Institute. January December 1982

Aremu, M, O., B. O. Atolaiye And L. Labaran, (2010)b, Environmental Implication Of Metal Concentrations In Soil, Plant Foods And Pond In Area Around The Derelict Udege Mines Of nasarawa State, Nigeria. Bull. Chem. Soc. Ethiop. 2010, 24(3), 351-360.

Aremu, M. O., D. U. Sangarib, E. I. Adeyeyec And Y. Y. Ishalekua (2010)a, Metal Concentration In Soils, Ponds And Associated Food Crops In Azara Derelict Baryte Mining Area In Nigeria. Electronic Journal Of Environmental, Agricultural And Food Chemistry, 9(1),1018.

Begum A., Ramaiah M., Harikrishna, Khan I., And Veena K. (2009) Analysis Of Heavy Metals Concentration In Soil And Litchens From Various Localities Of Hosur Road, Bangalore, India. E-Journal of Chemistry,6(1), 13-22.

Bello, A. L. (1973). The Morphology of an Erosional Scarp, South of Ahmadu Bello University, Zaria. Unpublished B. A Dissertation, Department of Geography, ABU, Zaria.

Bvenura C and Afolayan A J. (2012). Heavy metal contamination of vegetables cultivated in home gardens in the Eastern Cape. S. African Journal of Science. 108 (9/10)

Chopra A. K., Pathak C., and Prasad G. (2009) Scenario of heavy metal contamination in agricultural soil and its management. Journal of Applied and Natural Science 1(1), 99-108.

Ekundayo, E. O. (2003). Suitability of waste disposal sites for refuse disposal in Benin city, Nigeria.

Ezike N. N., Udiba U. U., Ogabiela E. E., Akpan N. S., Odey M. O., Inuwa B., Sule, A M.Gauje B. (2012), Assessment Of The Performance Of Primary Effluent Treatment Plant Of Major Tanneries In Kano, Nigeria, Journal of Trends in Advanced Science and Engineering, TASE 5(1), 38 - 45. 
GESAMP (IMO/FAO/Unesco/WMO/WHO/IAEA/UN/UNEP Joint Group of Experts on the Scientific Aspects of Marine Pollution), 1991. Reducing Environmental Impacts of Coastal Aquaculture. Rep. Stud. GESAMP, (47)35.

Hawkes, H. E. and Webb, J. S. (1962), Geochemistry in Mineral Exploration (pp 415), New York, NY: Harper and Row Publishers.

Iguisi, E. O. and Falade, A.M. (2009). Fluxes in Suspended Sediment Concentration and Total Dissolved Solids Upstream of the Galma. Dam, Zaria, Nigeria. A paper presented at the $21^{\text {st }}$ Annual Conference of the Nigeria Association of Hydro Geologists (NAH).

Jung, M. C. (2008). Heavy Metal Concentration in Soil and Factor Affecting Metal Uptake by Plants in the Vicinity of Korean Copper Tungsten Mine. Sensor, 8, 2413-2423.

Keen, C. L., (2001), Manganese As Essential And Possibly Toxic Mineral, Linus Pauling Institute, Oregun, Ipi@oregonstate. Edu.

Larbie C., Acquah S. J., Van-Ess H J., and Mak-Mensah E. E. (2014) Heavy metal contamination of Cabbage Sections from different farms in Ghana. 5 (8), 18-23.

Matini L., Ongoka P. R. and Tathy J. P. (2011). Heavy metals in soil on spoil heap of an abandoned lead ore treatment plant, SE Congo-Brazzaville. African Journal of Environmental Science and Technology, 5(2), 89-97.

Mosana C., L., Mapfaire, S. Mapurazi \& Makanda R. (2011), Assessment of Heavy Metal Accumulation in Wastewater Irrigated Soil and Uptake by Maize Plants (Zea Mays L) at Firle Farm in Harare, Journal of Sustainable Development 4(6), 132-137.

Nnaji C. J., Uzairu A., Harrison G.F.S. and Balarabe M. L. (2011) Effect of Pollution on the Physico-Chemical Parameters of Wate and Sediments of River Galma, Zaria, Nigeria. Research Journal of Environmental and Earth Sciences 3(4), 314-320.

Nnaji, J. C., Uzairu, A, Harrison, G. F. S. And Balarabe, M. L. (2007) Evaluation of Cadmium, Chromium, Copper, Lead And Zinc Concentrations in the Fish Head/Viscera of Oreochromis Niloticus and Synodontis Schall of River Galma, Zaria, Nigeria, Ejeafche, 6 (10), 2420-2426.

Ogbonna D. N., Kii B. L. and Youdeowei P. O. (2009). Some Physico-Chemical and Heavy Metal Levels in Soils of Waste Dumpsites in Port Harcourt Municipality and Environs. J. Appl. Sci. Environ. Manage,13(4), $65-70$.

Ogbonna, P, C. \& Okeke V. I (2011). Metal Content of Soil and Macronutrient of Gmelina Leaves in Umuahia, Nigeria, Journal of applied sciences in environmental sanitation, 6(1), 15-22.

Ologe, K. O. (1971). Gully Development in the Zaria Area, Northern Nigeria (with particular reference to the Kubanni Basin). Unpublished Ph.D Thesis University of Liverpool.

Thorp, M. B. (1970). Landforms of Zaria in Mortomire, M. J. (ed) Zaria and its Region Occasional Paper 4, Department of Geography, ABU, Zaria.

Udiba U. U., Gauje Balli, Ashade N. O., Ade-Ajayi F.A., Okezie V. C., Aji B. M., Abashe H (2014b). An Assessment of the Heavy Metal Status of River Galma around Dakace Industrial Layout, Zaria, Nigeria. Merit Research Journal of Environmental Science and Toxicology, 2(8), 176-184.

Udiba U. U., Inuwa Bashir, Akpan N. S., Ezike N.N., Zuru S. B. Anyanwu S. E., Saleh A. M (2014a). The Influence of Industrial Effluents from Dakace Industrial Area on the Heavy Metal profile of River Galma, Zaria, Nigeria. Advances in Applied Science Research, 5(6):165-17.

Udiba U. U., Ogabiela, E. E., Hammuel, C., Magomya, A.M., Yebpella, G. G., Ade-Ajayi, A.F., Odey, M. O. \& Gauje, B. (2012a) Post Remediation Assessment of Contaminants Levels in Soil, Dareta Village, Zamfara, Nigeria. Journal of Trends in Advanced Science and Engineering, TASE 4(1), 70-79.

Udiba, U. U., Ogabiela E. E., C. Hammuel, Ade-Ajayi A. F., Odey M. O., Yusuf U., Abdullahi M., Gauje Bali,(2012b), Assessment Of Some Environmental Pollutants In Soil, Dareta Village, Zamfara, Nigeria, Journal of Trends in Advanced Science and Engineering, TASE 5(1) pp $27-37$.

Udiba, U. U., Hassan Diya'uddeen B., Odey Michael O., Bashir Inuwa, Lasisi Aisha, Ade-Ajayi, Ade-Bola. F., Ezike Nkechi N. and

Umar Shittu M. (2013) Toxicological implications of grazing on forage grasses in Dareta Village, Zamfara, Nigeria, Archives of Applied Science Research, 5 (3), 220-228.

United Nations Environment Programme (2000) International Source Book on Environmentally Sound Technologies (ESTs) for Municipal Solid Waste Management (MSWM) <http://www.unep.or.jp/ietc/ ESTdir/Pub/MSW/index.asp

Uwah, E. I., Ndahi, N. P. \& Ogugbuaja V. O. (2009). Study of the Levels of Some Agricultural Pollutants in Soils and Water Leaf (Talinum Triangulare) Obtained in Maiduguri, Nigeria, Journal of Applied sciences in Environmental Sanitation, 4(2), 71-78.

Yahaya, M. I., Ezeh, G. C., Musa Y. F. \& Mohammad S. Y. (2010). Analysis of heavy metals concentration in road sides' soil in Yauri, Nigeria. African Journal of Pure and Applied Chemistry 4(3), 022-030.

Yebpella G. G, A. M. Magomya, U. U. Udiba, I. Gandu, S. M. Amana, V. C, Ugboaja, And N. I. Umana (2011). Assessment of Cd, Cu, Mn, and Zn levels in Soil, Water and Vegetables Grown in Irrigated Farms along River Kubani, Zaria, Nigeria. Journal of Applied Environmental and Biological Sciences, 1(5), 84-89.

Yusuf M. A. (2010). Evaluation of Heavy Metals in the Soils of Urban and Periurban Irrigated Land in Kano, Northern Nigeria. Bayero Journal of Pure and Applied Sciences, 3(2), 46 - 51. 